\title{
Purification and Biochemical Characterization of
}

\section{Nuclear Ribonucleoprotein Antigen using}

\author{
Purified Antibody from Serum of a \\ Patient with Mixed Connective Tissue Disease
}

\author{
Makoto Takano, Paul F. Agris, and Gordon C. Sharp, Division of Immunology \\ and Rheumatology, Department of Medicine and the Division of Biological \\ Sciences, University of Missouri-Columbia, Columbia, Missouri 65212
}

\begin{abstract}
A B S TRACT We have achieved a high degree of purification of nuclear ribonucleoprotein antigen from calf thymus nuclear extract through antibody affinity chromatography. Antibody to nuclear ribonucleoprotein was purified from the serum of a patient with mixed connective tissue disease and Sepharose 4B was covalently coupled with the purified human antibody. The sodium thiocyanate eluate from the affinity column contained active ribonucleoprotein antigen and the specific activity of the antigen in this eluate was 488 times higher than the original nuclear extract. The protein component of the eluate consisted of six polypeptides determined by sodium dodecyl sulfate-polyacrylamide gel electrophoresis. Two of them were shown to be antigenic by a hemagglutination inhibition test. The molecular weights of these two peptides were $\sim 13,000$ and those of the other four were 13,000 , $13,000,30,000$, and 65,000 . The ribonucleic acid component of the eluate was shown by urea-polyacrylamide gel electrophoresis to contain five polynucleotides. Two of the five, estimated to contain 40 and 60 nucleosides, had antigenic activity. The other three polynucleotides which had more than 77 nucleosides had no antigenic activity. No modified nucleosides were found in these ribonucleic acid molecules. Even in this highly purified ribonucleoprotein antigen, Sm antigen was detected by immunodiffusion. This evidence indicated that there are some molecular associations between ribonucleoprotein and $\mathrm{Sm}$ antigens as has previously been suggested.
\end{abstract}

Received for publication 6 September 1979 and in revised form 24 January 1980.

\section{INTRODUCTION}

Antibody to nuclear ribonucleoprotein (RNP) ${ }^{1}$ is almost always detected in very high titers by passive hemagglutination testing of the serum of patients with mixed connective tissue disease (MCTD) (1). This antibody is also found, although less frequently and in lower titers, in patients with systemic lupus erythematosus, progressive systemic sclerosis, or mild, undifferentiated connective tissue disease (2-5). Patients with antibody to RNP who are diagnosed as having systemic lupus erythematosus, progressive systemic sclerosis, and undifferentiated connective tissue disease tend to have some of the clinical features of MCTD (6). These findings suggest that immune reactions to RNP may play an important role in the development of some of the disease manifestations of patients with MCTD.

Although a precise pathological role has yet to be determined, the high frequency of detectable serum immune complexes in MCTD (7) and the deposition of antibody to RNP in the glomerular lesion in systemic lupus erythematosus (8) suggest that this antibody, in the form of immune complexes, may contribute to immune injury. The recent observation of AlarconSegovia $(9,10)$ that antibody to RNP can enter living $\mathrm{T} \gamma$ cells through their $\mathrm{Fc}$ receptors and bind to their nuclei suggests that another possible disease mechanism in MCTD might be an alteration of the biological

\footnotetext{
${ }^{1}$ Abbreviations used in this paper: CTE, calf thymus nuclear extract; ENA, extractable nuclear antigen; MCTD, mixed connective tissue disease; NaSCN, sodium thiocyanate; PBS, phosphate-buffered saline; RNP, nuclear ribonucleoprotein; SDS, sodium dodecyl sulfate.
} 
function of RNP, which is bound to its cognate antibody. Therefore, studies of the biological role of RNP might result in a better understanding of the pathogenesis of MCTD.

To perform such studies it is first necessary to purify and characterize the RNP antigen. An RNP antigen has been isolated and purified from rat liver extract (11). The purpose of this paper is to report our methods, which have achieved a high degree of purification of nuclear RNP antigen from calf thymus nuclear extract and the biochemical characterization of this purified antigen.

\section{METHODS}

\section{Selection of sera}

A reference serum monospecific for antibody to nuclear RNP was obtained from a patient with MCTD. The titer of antibody in whole serum to extractable nuclear antigen (ENA) by passive hemagglutination was 1:1,260,000. When sheep erythrocytes coated with ENA were digested with ribonuclease A (RNase) (1) before reaction with the positive reference serum, the hemagglutination titer was eliminated. This serum gave a single precipitin line against calf thymus nuclear extract (CTE) in agarose immunodiffusion. This precipitation reaction was abolished by treatment of CTE with RNase. Negative control serum was drawn from a healthy subject. In this serum, no antibody activity to ENA, CTE, or DNA was detected by hemagglutination or immunodiffusion. Reference sera for antibodies to Sm, PM-1, MA, Scl-1, SS-B, and DNA were used to determine antigen specificity of purified antigen.

\section{IgG preparation}

IgG was prepared by ammonium sulfate precipitation followed by DEAE-cellulose column chromatography according to the method described by Fahey and Horbett (12).

\section{Purification of antibody to RNP}

Purified antibody to RNP was obtained from immune precipitates made by mixing CTE and serum monospecific for antibody to RNP. The precipitates were washed three times with ice cold $0.01 \mathrm{M}$ phosphate-buffered saline (PBS) containing $0.15 \mathrm{M} \mathrm{NaCl}, \mathrm{pH} 7.4$, and dissolved in $0.01 \mathrm{M} \mathrm{HCl}$ solution. This solution was incubated at $56^{\circ} \mathrm{C}$ for $30 \mathrm{~min}$ to destroy RNP antigenic activity. Further purification was achieved through ammonium sulfate precipitation. The precipitate at $25 \%$ saturation was discarded; the next precipitate at $50 \%$ saturation collected by centrifugation was dissolved in the smallest volume of PBS and dialyzed against the same buffer for $36 \mathrm{~h}$. The purified antibody was shown to be pure immunoglobulin (Ig)G by immunoelectrophoresis and was monospecific for RNP in that it did not contain activity for Sm, PM-1, MA, Scl-1, SS-B, or DNA.

\section{Nuclear antigen preparation}

ENA and CTE were prepared by described methods $(1,13)$. After ultracentrifugation at $106,000 \mathrm{~g}$ for $2 \mathrm{~h}$, the CTE supernate was further fractionated using ammonium sulfate precipitation. The precipitate at $30 \%$ saturation was discarded, and the next precipitate at $60 \%$ saturation dissolved in PBS and dialyzed against PBS for $48 \mathrm{~h}$. The final protein concentration of this crude CTE was $15-20 \mathrm{mg} / \mathrm{ml}$.

\section{Agarose gel column chromatography}

Agarose gel column chromatography (Sepharose 6B, Pharmacia Fine Chemicals, Inc., Piscataway, N. J.) was used for partial purification of RNP antigen. The column was $2.5 \mathrm{~cm}$ Diam and $90 \mathrm{~cm}$ in length. PBS, $0.01 \mathrm{M}, \mathrm{pH} \mathrm{7.4}$, containing $0.5 \mathrm{M} \mathrm{NaCl}$ was used as running buffer. Blue dextran $(2,000,000$ mol. wt) and 7S IgG (160,000 mol wt) were used for molecular weight standards.

\section{Affinity chromatography}

In affinity chromatography used to purify RNP antigen, $0.5 \mathrm{~g}$ of cyanogen bromide-activated Sepharose $4 \mathrm{~B}$ was reacted with $2 \mathrm{ml}(5.2 \mathrm{mg})$ of purified antibody to RNP or the same amount of IgG from negative control serum in $0.1 \mathrm{M}$ $\mathrm{NaHCO}_{3}$ containing $0.5 \mathrm{M} \mathrm{NaCl}$ solution at $4^{\circ} \mathrm{C}$ for $18 \mathrm{~h}$ by gentle stirring with a magnetic stirrer. Remaining active groups were blocked with $1.0 \mathrm{M}$ ethanolamine and unbound protein was washed away from the gel according to the manufacturer's instruction. Under these conditions, the Sepharose $4 \mathrm{~B}$ gel was coupled with $>97 \%$ added IgG. The gel was then poured into a column, $0.9 \mathrm{~cm}$ Diam and $15 \mathrm{~cm}$ in length, and equilibrated with $0.01 \mathrm{M}$ PBS containing $0.5 \mathrm{M} \mathrm{NaCl}$, pH 7.4.

\section{Sodium dodecyl sulfate (SDS)-polyacrylamide slab gel electrophoresis}

Electrophoresis of crude and purified RNP antigen in SDSpolyacrylamide slab gels was performed according to the methods of Laemmli (14) and Weber and Osborn (15). The gels were formed as $1.5 \times 120 \times 106 \mathrm{~mm}$ slabs, which consisted of separating gels containing $8-13 \%$ gradient acrylamide and $0.1 \%$ SDS in Tris- $\mathrm{HCl} \mathrm{pH} 8.8$ with $15 \mathrm{~mm}$ of stacking gels containing $5 \%$ acrylamide and $0.1 \%$ SDS in Tris $\mathrm{HCl}, \mathrm{pH} 6.8$. To retain their antigenic activity, samples were not boiled. Gels were run at $150 \mathrm{~V}$, constant voltage at $4^{\circ} \mathrm{C}$. The proteins were stained with $0.04 \%$ Coomassie Brilliant Blue in $25 \%$ isopropyl alcohol, $10 \%$ acetic acid solution overnight. RNase $(13,700 \mathrm{~mol} \mathrm{wt})$, chymotrypsinogen $(25,000 \mathrm{~mol} \mathrm{wt})$, ovalbumin $(43,000 \mathrm{~mol} w \mathrm{t})$, and bovine serum albumin $(67,000$ mol wt) were used as molecular weight standards.

\section{Urea-polyacrylamide gel electrophoresis}

Ribonucleic acid content of purified RNP antigen was determined by polyacrylamide gel electrophoresis. Slab gels ( $1.5 \mathrm{~mm}$ thick; $16.5 \times 16.5 \mathrm{~cm}$ ) consisting of $10 \%$ acrylamide and $7 \mathrm{M}$ urea running gels were prepared and run as described

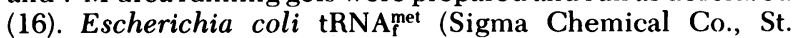
Louis, Mo.), $90 \%$ pure, was used as a molecular weight standard. Bromphenol blue and xylene cyanol FF were added to all samples; BPB marks the electrophoretic front and xylene cyanol FF migrates at a rate comparable to 5S RNA under the conditions used (16). Gels were run at $15 \mathrm{~mA}$ constant current. RNA was detected by staining the gels with ethidium bromide $\left(0.1 \mathrm{mg}\right.$ in $\left.200 \mathrm{ml} \mathrm{H}_{2} \mathrm{O}\right)$ for 40 min followed by rinsing with $\mathrm{H}_{2} \mathrm{O}$. Gels were photographed under a near ultraviolet lamp.

\section{Immunological methods}

Immunodiffusion. The Ouchterlony double immunodiffusion method was used to demonstrate and identify the 
precipitation reaction between the antibody to nuclear protein antigens in the reference serum and crude or purified antigen. $10 \mathrm{ml}$ of $0.4 \%$ agarose (Marine Colloids Div., F.MC Corp., Rockland, Maine) in 0.01 M PBS, pH 7.4, containing $0.15 \mathrm{M} \mathrm{NaCl}$ and $0.1 \% \mathrm{NaN}_{3}$, were pipetted onto glass plates $(8 \times 10 \mathrm{~cm})$. Wells of $7 \mathrm{~mm}$ Diam were placed $4 \mathrm{~mm}$ apart. The precipitin reaction was observed after 24,48 , and $72 \mathrm{~h}$.

Hemagglutination test. A passive hemagglutination test using ENA-coated sheep erythrocytes was performed by published methods (17).

Hemagglutination inhibition test. To detect antigenic activity of purified fractions, a hemagglutination inhibition test was performed in microtiter plates (U plate; Dynatech Laboratories, Inc., Alexandria, Va.). $50 \mu \mathrm{l}$ of 1:1,500 diluted serum monospecific for antibody to RNP, which had been inactivated at $56^{\circ} \mathrm{C}$ for $30 \mathrm{~min}$ and absorbed with sheep erythrocytes, were mixed with $50 \mu \mathrm{l}$ of various concentrations of antigens. After $30 \mathrm{~min}$ of incubation at room temperature, $100 \mu \mathrm{l}$ of ENA-coated sheep erythrocytes were added. The results were determined after $18 \mathrm{~h}$ incubation at $4^{\circ} \mathrm{C}$.

\section{Protein estimation}

Protein concentration was estimated with the method of Lowry et al. (18).

\section{Analysis of RNP nucleoside composition}

Qualitative and quantitative analysis of the major and minor nucleosides of the RNA of RNP antigen was accomplished according to our previously published methods (19).

\section{Amino acid composition of RNP}

A Beckman $121 \mathrm{M}$ amino acid analyzer, with a $45 \times 2.8-\mathrm{cm}$ column packed with Beckman AA-20 resin (Beckman Instruments, Inc., Fullerton, Calif.), was used for the amino acid analysis. A single column, isothermal $\left(51^{\circ} \mathrm{C}\right), 3$ buffer $\left(\mathrm{Na}^{+}\right)$ system and 3-h chromatography were used. The data handling system was a model 3352 B laboratory system from HewlettPackard Co., Palo Alto, Calif. Analysis was performed as described (20).

\section{RESULTS}

Purification of nuclear RNP. Partial purification of RNP from crude CTE was performed by Sepharose 6B column chromatography. As shown in Fig. 1, RNP antigenic activity was detected in the early fractions of the second peak of material (OD curve at $280 \mathrm{~nm}$.) eluting from the column. Since this antigenic activity and $7 \mathrm{~S} \mathrm{IgG} \mathrm{were} \mathrm{eluted} \mathrm{in} \mathrm{the} \mathrm{same} \mathrm{fractions,} \mathrm{the}$ molecular weight of this antigen is considered to be $\sim 160,000$.

These antigen-positive fractions were pooled and ammonium sulfate added to make a final concentration of $60 \%$ saturation. The resulting precipitate was dissolved in the smallest possible vol of $0.01 \mathrm{M}$ PBS, pH 7.4, containing $0.15 \mathrm{M} \mathrm{NaCl}$ and dialyzed against the same buffer for $36 \mathrm{~h}$ followed by dialysis against $0.01 \mathrm{M}$ PBS, pH 7.4, containing $0.5 \mathrm{M} \mathrm{NaCl}$ for $24 \mathrm{~h}$. The protein concentration of this partially purified CTE antigen was $13.2 \mathrm{mg} / \mathrm{ml}$.

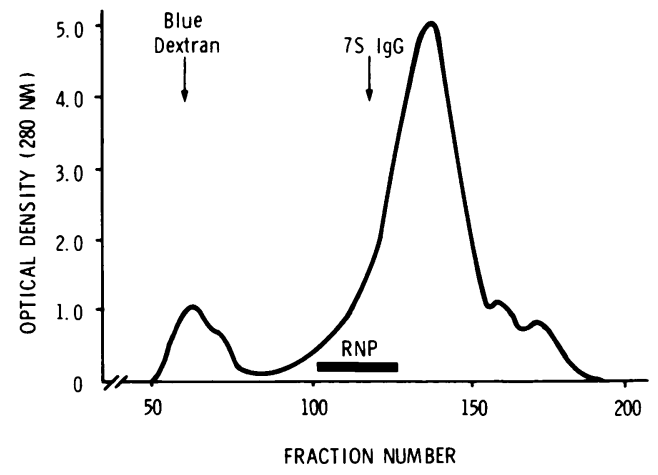

Figure 1 Partial purification of CTE with Sepharose 6B column chromatography. CTE $(6 \mathrm{ml}, 20 \mathrm{mg}$ protein/ml $)$ that had been obtained by ammonium sulfate precipitation (Methods) was subjected to agarose gel chromatography. RNP antigenic activity determined by immunodiffusion analysis was detected in early fractions of the second peak of an optical density curve. This activity was present in the same fractions as $7 \mathrm{~S}$ IgG.

To further purify RNP antigen, $2 \mathrm{ml}$ of partially purified antigen were applied to the antibody affinity

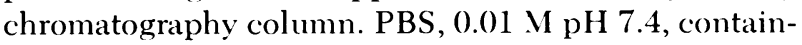
ing $0.5 \mathrm{M} \mathrm{NaCl}$ was used as a running buffer. The flow rate was adjusted to be $15 \mathrm{ml} / \mathrm{hr}$. After the protein concentration of the column fractions went to zero, the column was eluted with $3 . \mathrm{M}$ sodium thiocyanate (NaSCN) solution. The NaSCN eluate was dialyzed for $24 \mathrm{~h}$ against $0.01 \mathrm{M}$ PBS, $\mathrm{pH} 7.4$, containing $0.15 \mathrm{M}$ $\mathrm{NaCl}$ immediately after elution from the column. Table I shows the percentage of recovered protein and antigenic activity of the dialyzed NaSCN eluates. The $\mathrm{NaSCN}$ eluate from the antibody affinity column contained $1.41 \%$ of the total applied protein and had antigenic activity as determined by double immunodiffusion and hemagglutination inhibition tests. On the other hand, the eluate from the column that was coupled with IgG from negative control serum con-

TABLE I

Percent Protein Recovery and Antigenic Activities* in $3 . \mathrm{M}$ NaSCN Eluate from the Affinity Chromatography Column

\begin{tabular}{ccccc}
\hline & & \multicolumn{2}{c}{ NaSCX eluate } & \\
\cline { 3 - 4 } $\begin{array}{c}\text { Sepharose 4B } \\
\text { coupled with }\end{array}$ & $\begin{array}{c}\text { Applied } \\
\text { protein }\end{array}$ & $\begin{array}{c}\text { Recovered } \\
\text { protein }\end{array}$ & $\begin{array}{c}\text { Percent } \\
\text { recovered }\end{array}$ & $\begin{array}{c}\text { Antigenic* } \\
\text { activity }\end{array}$ \\
\hline & $m g$ & $m g$ & & \\
$\begin{array}{c}\text { Purified antibody } \\
\text { to RNP }\end{array}$ & 26.4 & 0.372 & 1.41 & Positive \\
$\begin{array}{c}\text { IgG from negative } \\
\text { control serum }\end{array}$ & 26.4 & 0.024 & 0.09 & Negative \\
\hline
\end{tabular}

* Determined by immunodiffusion test and hemagglutination inhibition test. 


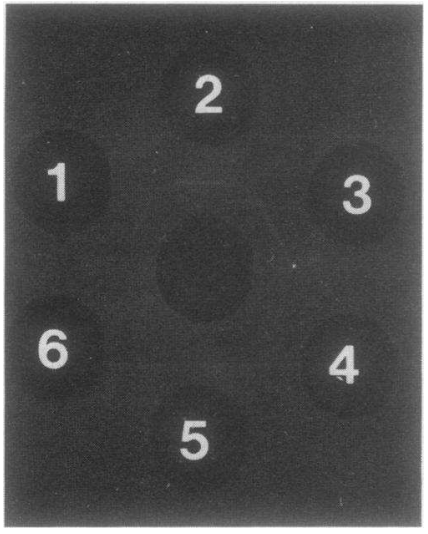

FIGURE 2 Completely identical precipitin lines among crude CTE, partially purified RNP, and purified RNP antigen against reference serum for antibody to RNP. Well 1 contained crude CTE; well 2, the NaSCN eluate; and well 3 , Sepharose 6B-fractionated CTE. Wells 4-6 contained the same samples as in wells 1-3, respectively, but these samples had been pretreated with RNase. The center well contained reference serum for antibody to RNP. Precipitin lines did not appear when the antigen was pretreated with RNase.

tained $<0.1 \%$ of the total applied protein and had no antigenic activity. Fig. 2 shows completely identical precipitin lines among crude, partially purified and purified antigens against reference serum for antibody to RNP. These lines were abolished by RNase treatment of antigens. Quantitative antigenic activities for these three antigens are compared in Table II. The NaSCN eluate was found to have very strong antigenic activity, $0.375 \mathrm{ng}$ of protein from this purified RNP inhibiting the hemagglutination test, compared to 183 ng of protein from crude CTE. The degree of inhibition showed that the NaSCN eluate was 488 times more active for RNP antigen than crude CTE.

Protein analysis of NaSCN eluate. As shown in Fig. 3 , SDS-polyacrylamide slab gel electrophoresis of the NaSCN eluate gave six polypeptide bands. Four of the six polypeptides comprised of two darkly stain- ing major bands and two lightly staining minor bands had molecular weights estimated as 12,000-13,000. The molecular weights of the larger polypeptides were $\sim 65,000$ and 30,000.

Elution of the individual polypeptides from the gel was performed as possible to determine which polypeptides contained antigenic activity. The whole gel was cut into $1-\mathrm{mm}$ wide slices from the bottom to the top. Each gel slice was homogenized in $100 \mu \mathrm{l}$ of $0.01 \mathrm{M}$ PBS, pH 7.4, containing $0.15 \mathrm{M} \mathrm{NaCl}$ and then centrifuged at $1,086 \mathrm{~g}$ for $10 \mathrm{~min}$. The supernatant fluid was examined for antigenic activity by hemagglutination inhibition. Antigenic activity was found in three areas in the gel. Two of these corresponded to the polypeptide bands that were located around the 13,000-mol wt area and the other was seen to be in the lower molecular weight portion of the gel, an area not stained with Coomassie Brilliant Blue.

Amino acid analysis was performed on the NaSCN eluate containing the peptides shown in Fig. 3. The total amino acid composition is depicted in Table III. No extraordinary amount of basic amino acids, that may be expected in a nucleic acid-protein complex, were found.

RNA analysis of NaSCN eluate. Purified RNP was enzyme-hydrolyzed to nucleosides and the nucleosides subjected to high performance liquid chromatography for determination of composition (19). The antigen's RNA was found to contain only the four major nucleosides. Relative amounts of the nucleosides were: adenosine, 3.11; uridine, 5.73; guanosine, 6.07; and cytosine, 6.65. The $(\mathrm{A}+\mathrm{U}) /(\mathrm{G}+\mathrm{C})$ ratio was 0.695 .

Urea-polyacrylamide gel electrophoresis of the NaSCN eluate showed the purified RNP antigen to be comprised of five polynucleotides (Fig. 4). One polynucleotide chain, designated band 1 , and two similarly sized chains, designated band 2 in Fig. 4, were larger than $E$. coli tRNA $_{f}^{\text {met }}$, which has 77 nucleosides. Two smaller polynucleotides, bands 3 and 4 , could be estimated to be of 60 and 40 nucleosides in length,

TABLE II

Comparison of Quantitative Antigenic Activities among Crude, Partially Purified, and Purified Antigens

\begin{tabular}{lccc}
\hline & \multicolumn{2}{c}{ Hemagglutination inhibition test } & \\
\cline { 2 - 4 } & $\begin{array}{c}\text { Minimum inhibiting } \\
\text { protein concentration }\end{array}$ & $\begin{array}{c}\text { Minimum inhibiting } \\
\text { amount of protein }\end{array}$ & $\begin{array}{c}\text { Purification } \\
\text { index* }\end{array}$ \\
\hline & 3.66 & $n g$ & \\
$\begin{array}{l}\text { Crude CTE } \\
\begin{array}{l}\text { Sepharose 6B- } \\
\text { fractionated CTE }\end{array}\end{array}$ & 0.32 & 183 & 1 \\
$\begin{array}{l}\text { NaSCN eluate } \\
\text { * Minimum inhibiting amount of protein of crude CTE/minimum inhibiting }\end{array}$ & 16 & 11.4 \\
amount of protein of purified fraction. & 0.0075 & 0.375 & 488 \\
\end{tabular}




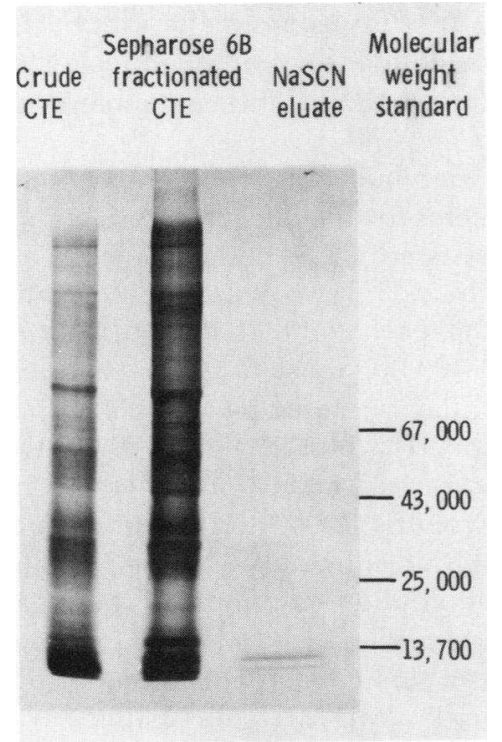

FIGURE 3 SDS-polyacrylamide slab gel electrophoresis of crude, partially purified, and purified antigens. The NaSCN eluate gave six polypeptide bands stained with $0.04 \%$ Coomassie Brilliant Blue. Four of the six bands had molecular weights estimated at 12,000-13,000. The molecular weights of the larger polypeptides were $\sim 65,000$ and 30,000 .

respectively. Hemagglutination inhibition tests of the four bands and in addition two blanks of gel remote from any ethidium bromide-staining material, showed that only bands 3 and 4 were antigenic.

Antigenic specificity of the NaSCN eluate. The $\mathrm{NaSCN}$ eluate gave no immunodiffusion precipitin line

TABLE III

Amino Acid Composition of NaSCN Eluate

\begin{tabular}{lrrr}
\hline Amino acid & Micrograms* $^{*}$ & Nanomoles & Moles \\
\hline & & & $\%$ \\
ASP & 13.2 & 99.2 & 10.4 \\
Thr & 5.7 & 47.9 & 5.0 \\
Ser & 5.8 & 55.3 & 5.8 \\
Glu & 17.4 & 118.3 & 12.4 \\
Pro & 5.4 & 47.1 & 4.9 \\
Gly & 6.2 & 82.3 & 8.6 \\
Ala & 5.7 & 64.0 & 6.7 \\
Cys & 1.3 & 5.5 & 0.6 \\
Val & 7.8 & 64.6 & 6.8 \\
Met & 2.5 & 16.8 & 1.8 \\
Ile & 6.9 & 52.7 & 5.5 \\
Leu & 11.5 & 87.7 & 9.2 \\
Tyr & 4.5 & 25.0 & 2.6 \\
Phe & 5.8 & 35.1 & 3.7 \\
His & 3.5 & 22.4 & 2.3 \\
Lys & 11.4 & 78.0 & 8.1 \\
Arg & 9.7 & 55.9 & 5.8 \\
\hline
\end{tabular}

* Micrograms per $0.5 \mathrm{~g}$ of $\mathrm{NaSCN}$ eluate, approximate values.

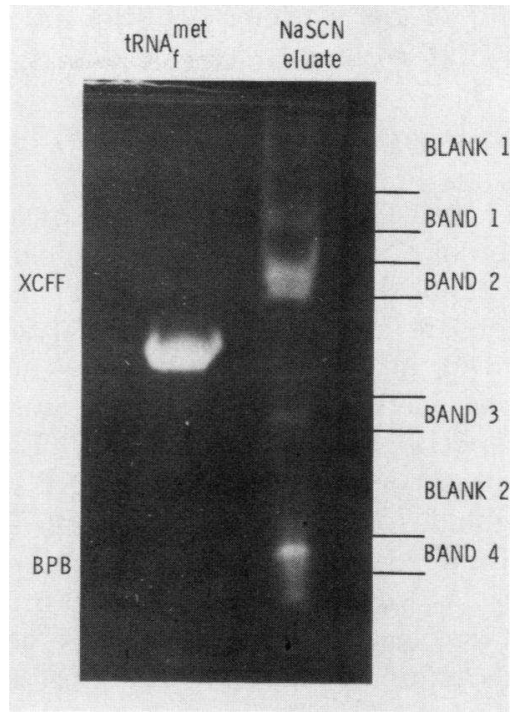

FIGURE 4 Urea-polyacrylamide gel separation of RNA contained in the NaSCN eluate. The NaSCN eluate ( $5 \mu \mathrm{g}$ RNA) and $E$. coli tRNA $\mathrm{f}_{\mathrm{f}}^{\text {met }}(10 \mu \mathrm{g})$ were subjected to urea-polyacrylamide gel electrophoresis. The gel was stained with ethidium bromide revealing the presence of four bands of polynucleotides in the purified RNP antigen and the location of tRNA $\mathrm{f}_{\mathrm{f}}$. Areas designated by bands $1-4$ and blanks 1 and 2 were assayed for antigenicity by the hemagglutination inhibition test. Only bands 3 and 4 RNA molecules with molecular weights of $\sim 18,000$ and 12,000 , respectively, gave positive results.

against reference sera for antibody to PM-1, MA, Scl-1, and SS-B but did contain Sm antigenic activity as shown in Fig. 5. However, investigation of material eluted from SDS-polyacrylamide gel showed no Sm activity could be detected by hemagglutination inhibi-

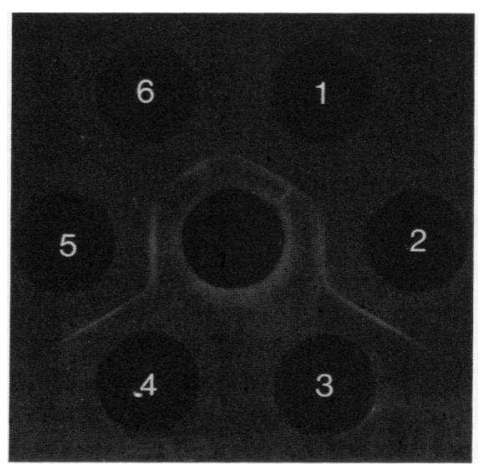

FIGURE 5 Demonstration of Sm antigen in the NaSCN eluate by immunodiffusion. The center well contained reference serum for antibody to RNP and Sm. Well 1 contained crude CTE digested with RNase A; well 2, crude CTE; well 3, reference serum monospecific for antibody to RNP; well 4, the same serum as in well 3; well 5 , the $\mathrm{NaSCN}$ eluate; and well 6 , the NaSCN eluate digested with RNase. Sm-anti-Sm precipitin lines between the center well and wells $1,2,5$, and 6 are completely identical. 
tion testing of the various peptides in contrast to results for RNP antigen.

\section{DISCUSSION}

This paper describes a methodology for achieving a high degree of purification of CTE nuclear RNP antigen. Biochemical and immunological analyses of this antigen are also described. A dialyzed NaSCN eluate from the anti-RNP affinity column contained immunologically active RNP antigen that was 488 times higher in specific activity than crude CTE. In control experiments, when partially purified RNP antigen was passed through a column of Sepharose 4B coupled with IgG from negative control serum and eluted with $3 \mathrm{M} \mathrm{NaSCN},<0.1 \%$ of the total applied protein could be eluted and no detectable antigenic activity was found. This finding indicates that affinity chromatography with purified antibody was the method of choice to obtain purified RNP antigen. However, when the NaSCN eluates had not been dialyzed against PBS, no precipitin line was observed in immunodiffusion tests. Therefore, it is important to dialyze this eluate against PBS as soon after elution as possible.

Recently, Douvas et al. (11) described the characterization of nuclear RNP antigen isolated with affinity chromatography. There are some significant differences in the methods employed by Douvas et al. and ourselves. They used rat liver nuclear extract as a crude nuclear antigen, whereas we have used CTE. But more importantly, (a) they coupled Sepharose 4B gel with IgG from the serum of patients with MCTD, whereas we used purified antibody to RNP instead of the IgG fraction; and $(b)$ they eluted RNP antigen from the column with $0.01 \mathrm{M} \mathrm{HCl}$ solution containing $0.15 \mathrm{M} \mathrm{NaCl}$, whereas we used a $3 \mathrm{M} \mathrm{NaSCN}$ solution. By coupling Sepharose 4B gel with purified antibody to RNP, we could reduce nonspecific adsorption of protein to the column. When our affinity column was eluted with $0.01 \mathrm{M} \mathrm{HCl}$, we also found antigenic activity for RNP in this eluate. However, after $\mathrm{HCl}$ elution, we could obtain an additional amount of more tightly bound antigen by eluting with $3 \mathrm{M} \mathrm{NaSCN}$. The ratio of $A_{280} / A_{260}$ for the $\mathrm{HCl}$ eluate tended to be much higher than that of the subsequent $\mathrm{NaSCN}$ eluate. Furthermore, the specific activity for RNP antigen of the $\mathrm{HCl}$ eluate was much lower than that of the NaSCN eluate. These findings suggested that $\mathrm{HCl}$ dissociates nonspecifically bound proteins and some specifically bound RNP antigen from antibody but the greater portion of the nucleic acid-rich RNP molecules were not eluted by the $\mathrm{HCl}$ solution. The $\mathrm{HCl}$ eluate in the study of Douvas et al. produced a precipitin line partially identical with that of crude antigen. Whereas in this study, precipitin lines of the dialyzed NaSCN eluate and CTE antigen against the serum of a patient with MCTD were completely identical. Thus, the NaSCN eluate probably contained less degraded, more highly purified RNP antigen molecules than the $\mathrm{HCl}$ eluate.

SDS-polyacrylamide gel electrophoresis of the NaSCN disclosed that the protein component of this antigen consisted of six polypeptides. The molecular weights of four of the six polypeptides were estimated to be $\sim 13,000$ each and that of the remaining two were 65,000 and 30,000 . Some of these peptides seemed to be very similar in molecular weight to peptides contained in the $\mathrm{HCl}$ eluate described by Douvas et al. They reported two main polypeptide components of molecular weights 13,000 and 30,000 were found in the $\mathrm{HCl}$-eluted RNP antigen. By indirect means they were able to attribute the immunoprecipitating ability of the RNP antigen to the $13,000-\mathrm{mol}$ wt component in that the affinity of this component for column-bound antiRNP antibodies was RNase sensitive. We have confirmed and further elucidated this finding. Antigenic activities of gel-separated polypeptides were examined directly by the hemagglutination inhibition test. In repeated experiments we have consistently found that only two of the four peptides located in the 13,000mol wt area had antigenic activity. We could also find a third region of antigenic activity in the gel at a location representative of a small molecular weight material but no protein band was evident. This may be attributable to the higher sensitivity of the hemagglutination inhibition test compared to the sensitivity of the Coomassie Blue staining for protein. This third antigenically active portion seemed to be of very small molecular weight. It might be some degraded part of the whole RNP molecule.

A nucleic acid-protein complex such as the RNP antigen might be expected to have protein containing a larger than average number of basic amino acids. Amino acid composition analysis of the RNP antigen showed that the amounts of lysine and arginine were not high. However, the antigen of the NaSCN eluate is composed of some six polypeptides. Analysis of the composite may have hidden the fact that one or more of the peptides have higher than average amounts of basic amino acid residues and are responsible for the proteinnucleic acid interaction.

The RNA component of the NaSCN eluate was separated into five polynucleotides upon the ureapolyacrylamide gel electrophoresis. Three polynucleotide chains of lengths larger than 77 nucleosides did not exhibit antigenic activity. Whereas two smaller polynucleotides, estimated to be 40 and 60 nucleosides in length, were antigenic. The larger RNA molecules may not contribute to the structure of the antigenic site for RNP. Alternatively, they may have lost their antigenic activity by being selectively stripped of protein during urea-gel electrophoresis. The smallest 
RNA component, estimated at 40 nucleosides in length, could have been generated from the next largest molecule by nonspecific ribonuclease action during purification. Sequence analysis of the two antigenic molecules, now in progress, will determine if they are related.

Nucleoside composition analysis of RNA from purified RNP revealed the total absence of modified nucleosides. The technique we employed for detecting modified nucleosides is capable of detecting less than one modified nucleoside per thousand nucleosides (19). Most RNA, including mRNA, contain modified nucleosides (21). Since notable exceptions are 5S RNA and heteronuclear RNA, it is possible that RNA from RNP antigen is derived from these RNA molecules. The RNA did contain almost equal molar amounts of guanosine and cytosine. This could be indicative of some secondary structure in the RNA of RNP.

Purified RNP, as the NaSCN eluate from the antibody affinity column, had Sm antigenic activity as well. Immunodiffusion tests showed no antigenic activities for PM-1, MA, Scl-1, and SS-B. Sm could have been retained and then eluted from the column with RNP in $3 \mathrm{M} \mathrm{NaSCN}$ for a number of reasons: (a) Specific adsorption to anti-Sm antibody that contaminated the anti-RNP antibody used in preparation of the column; (b) nonspecific adsorption to any IgG or to the column matrix, Sepharose; or (c) molecular association of $\mathrm{Sm}$ with RNP. However, purified antibody to RNP, used in affinity chromatography, did not contain antibody to $\mathrm{Sm}$ (Methods), nor was any Sm antigenic activity found in the $\mathrm{NaSCN}$ eluate from the negative control IgG affinity column. Therefore, RNP and Sm may exist in a molecular complex as suggested by Mattioli and Reichlin (22). The separate RNP and $\mathrm{Sm}$ precipitin lines shown in Fig. 5 might be caused by dissociation of a molecular complex or to the relatively different concentrations of antibodies to RNP and Sm used. However, Northway and Tan (13) described these two antigens as being different macromolecules. Douvas et al. (11), who found no precipitin reaction between their purified RNP antigen and anti-Sm serum, suggested that there are no physical associations between the two antigens.

Elution of bands from SDS-polyacrylamide gel and subsequent testing by hemagglutination inhibition was not successful in disclosing which peptides of the NaSCN eluate contributed to antigenic activity for Sm. Recently, Lieu and Tan (23) suggested that antigenic activity of $S m$ was detected in a protein of $\sim 70,000 \mathrm{~mol}$ wt. Therefore, the peptide of 65,000$)$ mol wt in the NaSCN eluate may have $S m$ antigenic activity.

Thus, RNP antigen is minimally composed of two polypeptides of some $13,000 \mathrm{~mol}$ wt each, which are complexed with RNA of some 60) and 40 nucleosides.
Four peptides of $13,000,13,000,30,000$, and 65,000 mol wt, and three RNA polynucleotide chains that have more than 77 nucleosides may also be part of the complex. An Sm antigenic site may exist in some of these molecules.

The purification and biochemical characterization of the RNP antigen achieved by Douvas et al. (11) and in our laboratory should facilitate more incisive studies of the possible biological role of the RNP system and its relationship to $\mathrm{Sm}$. Such studies may result in a better understanding of the pathogenesis of MCTD and related rheumatic diseases.

\section{ACKNOWLEDGMENTS}

We thank Susan Golden for her excellent technical assistance and Dianne Porter and Sharon Mitchell for preparation of the manuscript.

This research was supported by a grant from the U. S. Public Health Service (Am 20305), a grant from the Arthritis Foundation, a grant from the J. B. Reynolds Foundation, the University of Missouri Center for Aging Studies, and the Division of Biological Sciences.

\section{REFERENCES}

1. Sharp, G. C., W. S. Irvin, E. M. Tan, R. G. Gould, and H. R. Holman. 1972. Mixed connective tissue disease-An apparently distinct rheumatic disease syndrome associated with a specific antibody to an extractable nuclear antigen (ENA). Am. J. Med. 52: 148-159.

2. Parker, M. D. 1973. Ribonucleoprotein antibodies: frequency and clinical significance in systemic lupus erythematosus, scleroderma, and mixed connective tissue disease. J. Lab. Clin. Med. 82: 769-775.

3. Notman, D. D., N. Kurata, and E. M. Tan. 1975. Profiles of antinuclear antibodies in systemic rheumatic diseases. Ann. Intern. Med. 83: 464-469.

4. Bresnihan, B., C. Bunn, M. L. Snaith, and G. R. V. Hughes. 1977. Anti-ribonucleoprotein antibodies in connective tissue diseases: estimation by counterimmunoelectrophoresis. Br. Med. J. 5: 610-611.

5. Grennan, D. M., C. Bunn, G. R. V. Hughes, and W. W. Buchanan. 1977. Frequency and clinical significance of antibodies to ribonucleoprotein in SLE and other connective tissue disease subgroups. Ann. Rheum. Dis. 36: $442-447$.

6. Takano, M. 1978. Clinical significance of antibodies to nuclear ribonucleoprotein in collagen diseases. Ryumachi (Tokyo). 18: 256-266.

7. Halla, J. T., J. E. Volanakis, and R. E. Schrohenloher. 1979. Circulating immune complexes in mixed connective tissue disease. Arthritis Rheum. 22: 484-489.

8. Kurata, N., I. Hara, S. Miyawaki, and T. Ofuji. 1979. Heterogeneity of glomerular immune complexes in patients with systemic lupus erythematosus. Arthritis Rheum. 22: 632. (Abstr.)

9. Alarcon-Segovia, D., A. Ruiz-Arguelles, and E. Fishbein. 1978. Antibody to nuclear ribonucleoprotein penetrates live human mononuclear cells through $\mathrm{Fc}$ receptors. Nature (Lond.). 271: 67-69.

10. Alarcon-Segovia, D., A. Ruiz-Arguelles, and L. Llorente. 1979. Antibody penetration into living cells. II. Antiribonucleoprotein IgG penetrates into $\mathrm{T} \gamma$ lymphocytes causing their deletion and the abrogation of suppressor function. J. Immunol. 122: 18.55-1862. 
11. Douvas, A. S., W. E. Stumpf, P. Reyes, and E. M. Tan. 1979. Isolation and characterization of nuclear ribonucleoprotein complexes using human anti-nuclear ribonucleoprotein antibodies. J. Biol. Chem. 254: 3608-3616.

12. Fahey, J. L., and A. P. Horbett. 1959. Human gamma globulin fractionation on anion exchange cellulose columns. J. Biol. Chem. 234: 2645-2651.

13. Northway, J. D., and E. M. Tan. 1972. Differentiation of antinuclear antibodies giving speckled staining patterns in immunofluorescence. Clin. Immunol. Immunopathol. 1: 140-154.

14. Laemmli, U. K. 1970. Cleavage of structural proteins during the assembly of the head of bacteriophage T4. $\mathrm{Na}$ ture (Lond.). 227: 680-685.

15. Weber, K., and M. Osborn. 1969. The reliability of molecular weight determination by dodecyl sulfate-polyacrylamide gel electrophoresis. J. Biol. Chem. 244: 4406-4412.

16. Agris, P. F., T. Powers, D. Soll, and F. H. Ruddle. 1974. Methods for analysis of transfer RNA molecules from normal, neoplastic and induced mammalian cells. Cancer Biochem. Biophys. 1: 69-77.

17. Sharp, G. C., W. S. Irvin, R. L. LaRoque, C. Velez, V. Daly, A. D. Kaiser, and H. R. Holman. 1971. Association of autoantibodies to different nuclear antigens with clinical patterns of rheumatic disease and responsiveness to therapy. J. Clin. Invest. 50: 350-359.

18. Lowry, O. H., N. J. Rosenbrough, A. L. Farr, and R. J. Randall. 1951. Protein measurement with the Folin phenol reagent. J. Biol. Chem. 193: 265-275.

19. Davis, G. E., C. W. Gehrke, K. C. Kuo, and P. F. Agris. 1979. Major and Modified nucleosides in tRNA hydrolysates by high performance liquid chromatography. J. Chromatogr. 173: 281-298.

20. Agris, P. F., D. Setzer, and C. W. Gehrke. 1977. Characterization of a unique enzyme complex composed of $S$ adenosyl-L-methionine tRNA methyltransferase and aminoacyl-tRNA synthetase activities. Nucl. Acid. Res. 4: 3803-3819.

21. Agris, P. F., and D. Soll. 1978. The modified nucleosides of transfer RNA. In Nucleic Acid-Protein Recognition. $\mathbf{H}$. Vogel, editor. Academic Press, Inc., New York. 321-344.

22. Mattioli, M., and M. Reichlin. 1973. Physical association of two nuclear antigens and mutual occurrence of their antibodies: the relationship of the $\mathrm{Sm}$ and RNAprotein (Mo) systems in SLE sera. J. Immunol. 110: 1318-1324.

23. Lieu, T. S., and E. M. Tan. 1979. Purification of a nuclear nonhistone protein ( $\mathrm{Sm}$ antigen) reacting with the sera of patients with systemic lupus erythematosus. Arthritis Rheum. 22: 635. (Abstr.) 